\title{
Bank-Specific and Macroeconomic Determinants of Profitability: A Revisit of Pakistani Banking Sector under Dynamic Panel Data Approach
}

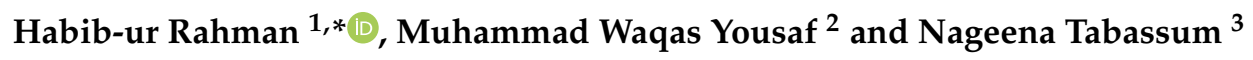 \\ 1 Department of Higher Education (Accounting and Finance), Holmes Institute, \\ Gold Coast, QLD 4217, Australia \\ 2 Pakistan Institute of Development Economics, Islamabad 44000, Pakistan; waqas_yousaf@hotmail.com \\ 3 School of Business, Western Sydney University, Sydney 2000, Australia; nageena_rana@yahoo.com \\ * Correspondence: hrahman@holmes.edu.au
}

Received: 8 February 2020; Accepted: 29 June 2020; Published: 7 July 2020

\begin{abstract}
This study aims to examine the effect of the bank-specific and macroeconomic determinants of profitability for the banking sector of Pakistan. To incorporate the issues of endogeneity, unobserved heterogeneity, and profit persistence, we apply a generalised method of moments (GMM) technique under the Arellano-Bond framework to a panel of Pakistani banks that covers the period 2003-2017. The results of a dynamic panel data approach reveal that capital adequacy accelerates the profitability of the banking sector in Pakistan. Capital adequacy helps the financial system to absorb any negative shock by reducing the number of bank failures and losses. Conversely, our empirical investigation reveals that the liquidity ratio, business mix indicators, interest rates, and industrial production deteriorates the bank profitability. Liquidity risks enhance the probability of default risks and transmit into the unpaid loans and hence the lower return. Our empirical evidence further reveals that Pakistani banks are not getting any benefit of the economies of scale in terms of financial performance.
\end{abstract}

Keywords: bank profitability; capital adequacy; return on assets; return on equity; macroeconomic; dynamic panel; banking sector; Pakistan

JEL Classification: C23; G21; L2

\section{Introduction}

Financial intermediaries play important financial roles in the economic and financial systems through offering a mechanism for payments (Allen and Gale 2004), matching the supply and demand of financial markets (Adrian and Shin 2008; Beck 2001), tackling complex financial instruments (Matherat 2008; Levine 1996), providing the transparency in markets, conducting risk transfer (Scholtens and Van Wensveen 2000), and handling the risk management roles (Allen and Santomero 2001; Scholtens and Van Wensveen 2000). In most economies, banks are the most important financial intermediaries which provide a range of services (also see Allen and Santomero 2001). The contemporary economic and financial operating system of these economies requires the efficiency of their banks to ensure their economic growth (Seven and Yetkiner 2016; Papadopoulos 2010). Conversely, the inefficiency and insolvencies in the banks lead to the financial crisis (also see Thakor 2018). Despite the bank disintermediation in some other economies, the role of banks remains central in financing economic activities at different levels (Athanasoglou et al. 2008). Apart from economic growth, a profitable banking system enables an economy to observe adverse shocks better and contribute to the economic and financial stability. Therefore, the academicians, management of banks, regulatory 
authorities, and researchers are highly interested in investigating the internal and external determinants of bank profitability.

In the Pakistani financial system, the banking system holds a key position since the regulatory structure allows commercial banks to serve different types of financial market activities (Zheng et al. 2019). Since 1970, commercial banks in Pakistan have dominated the financial system. However, these banks were unable to efficiently achieve their national socio-economic goals which lead to the nationalisation process in the bank sector of Pakistan (also see Khan and Hanif 2019). By the late 1990s, the public sector held almost 90 percent of the share in the banking industry and the multinational banks held the rest of the share since there were no domestic banks during that period. During this period, it was realised that the nationalised banking sector and non-banking financial institutions had deteriorated the operational performance of the financial system of Pakistan. As a result, the regulatory bodies made some significant changes in the Pakistani banking sector after 1997. In particular, these regulatory bodies restructured the banking policy, management and supervisory processes by following the best banking practices of developed economies. The economic analysts and the senior management of the banks are concerned with accomplishing the profitability objectives for the financial institutions. The profitability of commercial banks also posits a significant impact on the growth of the economy. These structural changes accelerated the economic growth of Pakistan in recent decades. This indicates that the operational structure and performance of the Pakistani banking sector depends upon the institutional, regulatory, macroeconomic and bank-specific factors.

In the last two decades, the operating environment of Pakistani banking sectors has experienced some significant episodes of transformation. Pakistani banks have shifted their lending from the government sector to the private sector in recent years. The financial sector of Pakistan is going through a couple of transitions. For instance, new groups are buying out the Pakistan operations of different foreign banks. In this way, the number of listing banks are increasing. These transformation episodes influence the determinants of profitability of the banking sector. Furthermore, the existing empirical literature on the determinants of bank profitability might be subject to the issue of profit persistence, and the estimated coefficients might be biased and inconsistent (Bourke 1989; Demirguc-Kunt and Huizinga 2001; Molyneux and Thornton 1992; Short 1979; Athanasoglou et al. 2008). Therefore, we apply a generalised method of moments (GMM) technique under the Arellano-Bond framework to a panel of Pakistani banks that covers the period 2003-2017. This paper aims to research the determinants of commercial banks' profitability in Pakistan from 2003 to 2017. Recently, different studies (Tan 2016, 2017; Tan and Floros 2012a, 2012b, 2012c; Tan et al. 2017) applied one-step and two-steps GMM estimators to investigate some determinants of bank profitability. Our study contributes to the existing empirical literature through a couple of ways. To the best of our knowledge, it is the first study to apply the GMM technique under the Arellano-Bond framework to analyse the micro and macro determinants of the Pakistani banking sector.

The remainder of the paper is structured as follows. Section 2 provides the context to the existing literature, which relates to the profitability of the bank to its determinants. Section 3 elaborates the research method, variables, data and method of analysis. We present and discuss the results of this research in Section 4. We conclude this study in the final section.

\section{Literature Review and Empirical Conjectures}

Existing empirical literature articulates bank profitability as a function of internal and external determinants (Athanasoglou et al. 2008). The organisation can measure profitability through a wide range of financial ratios. The most manifesting ratios as envisaged from prior literature are the return on assets, return on equity, net interest margin and return on investment (Flamini et al. 2009; Naceur and Goaied 2008; Vallelado and Saona 2011). The research scholars have been interested in determining the impacts of the macro or microeconomic factors to increase the profitability levels. Internal determinants can be termed as the micro or bank-specific determinants of the profitability of the banking sector. Conversely, external determinants are not linked with the operational efficiency of the bank management 
(Staikouras and Wood 2004) and reflect the legal and economic environment of an economy which affects the operational and financial performance of financial institutions (Naceur and Omran 2011). In this framework, the existing empirical research proposes several explanatory variables. One strand of empirical literature focuses on the cross-country analysis (Bikker and Hu 2002; Bourke 1989; Demirguc-Kunt and Huizinga 2001; Molyneux and Thornton 1992; and Short 1979). In particular, Bikker and $\mathrm{Hu}$ (2002) emphasise the linkages between the profitability and the business cycle. Another strand of literature focuses on the individual country analysis, including the USA and some emerging economies (Barajas et al. 1999; Berger et al. 1987). All of these studies use both internal and external determinants for bank profitability. Interestingly, the results of these studies vary significantly due to the different economic and legal environment as well as the use of different datasets. Despite this, we can categorise the empirical literature on the determinants of bank profitability based on some common elements.

\subsection{Internal Determinants of Bank Profitability}

Existing research reveals that liquidity, risk management, leverage, management of expense, deposit liability size, bank credit portfolio constitution and size, the policy adopted for the interest rate, risk-related exposures, quality of the management, as well as the age and size of the banks, ownership structure and the concentration of the banks, structural affiliation and the productivity of the labour are the most apparently employed internal factors, and these indicators measure the bank-specific performance. Nevertheless, other factors may contribute to the profitability levels within an organisation. These factors are inclusive of multi-dimensional reporting, the acknowledgement of the operating and income expenses, and capital allotment (Gounder and Sharma 2012). The profitability levels depend upon the variables above and they show different impacts on the different period of times. One strand of empirical literature focuses on internal determinants, including the capital, bank size, risk management, and expense management. The economic theory reveals that bank profitability might be subject to economies or diseconomies of the scale (also see Kosmidou 2008). The internal determinant, the bank size, accounts for the economies or diseconomies of scale (Shepherd 1972). ${ }^{1}$ This aspect is exciting for the case of Pakistan due to some structural changes over the last two decades (Badunenko and Kumbhakar 2017). Smirlock (1985) reports a positive and significant association between the bank's size and profitability. Mule et al. (2015) also report a positive association between the return on equity, profitability and firm size. They further reveal that the unit changes in the size of the firm are directly proportional to the return on investment. Similarly, Demirguc-Kunt and Huizinga (2001) further suggest that other legal, economic, financial, and other determinants (including corruption) of bank profitability depend upon the size of the institution.

Interestingly, Short (1979) argues that institutional size is closely linked with the capital adequacy since the larger financial institutions can quickly get less expensive capital which finally contributes towards the higher profitability. ${ }^{2}$ Niresh and Velnampy (2014) reveal that the firm size has no profound effect on the profitability of the firm. Conversely, some studies disagree with this nexus of size adequacy and profitability (see Berger et al. 1987; Shepherd 1972).

Turning now to the capital structure, ${ }^{3}$ there is enough evidence that the capital structure evaluates the number of financial resources involved in making total financial obligations for a company. In this framework, capital structure plays a critical role for any firm by providing an opportunity to increase the organisational profitability and the overall value of an organisation. Existing empirical literature reveals mixed evidence, including positive (Abor 2005; Nikoo 2015; Umar et al. 2012; Salteh et al. 2012;

1 The production capacity of the bank, the numerous services the bank provides, the quality and quantity of the services that the banks may offer to its prospects at a given time determines the size of the banks (Sritharan 2015).

2 Bikker and $\mathrm{Hu}$ (2002) also reveal the similar theoretical justification on the linkage between size, capital adequacy and profitability.

3 See Modigliani and Miller (1958) for further details on capital structure. 
Arbabiyan and Safari 2009), negative (Ramadan and Ramadan 2015; Abdel-Jalil 2014; Memon et al. 2012; Muritala 2012; Soumadi and Hayajneh 2012; Salim and Yadav 2012; Manawaduge et al. 2011; and Chakraborty 2010) and no association (Al-Taani 2013; Ebaid 2009).

Risk management is an integral part of the banking operation and affects the operational efficiency of the banking sector (Jizi and Dixon 2017). Incapability to perform the credit risks evaluation and assessment leads to the financial crises (Njanike 2009). On these lines, Athanasoglou et al. (2008) reveal that low liquidity and weak asset quality lead towards banking failures. ${ }^{4}$ Higher risk puts pressure on the management and ultimately, higher ups decide to diversify their portfolio and raise their liquid holdings to mitigate the risk. In this framework, the risk is bifurcated into credit risk and liquidity. Tan and Floros (2012c) extended this literature by incorporating stock market volatility. They applied the GMM difference and system estimator and revealed that the higher level of stock market volatility enhances the return on equity in the Chinese banking sector. Depending upon the specific nature of the Pakistani banking sector, we included both types of risk as the micro determinants. The higher the amount of credit and liquidity risks is transmitted into the unpaid loans, the lower the return. In this theoretical framework, existing empirical literature reveals that credit risk (Miller and Noulas 1997) and liquidity risks (Molyneux and Thornton 1992) deteriorate bank profitability. The economic theory states that the profitability and risks have a positive association. Higher liquidity reduces the level of risk and hence the profitability. In this balance structure, the working capital strategy appears less risky in context. For further evidence on liquidity and profitability, see Aduda and Gitonga (2011), Boahene et al. (2012), Gakure et al. (2012), and Kolapo et al. (2012). In the current globalised scenario, the presence of adequate liquidity is significant to assure long-term sustainability. In this context, liquidity is one of the widely used bank-specific determinants of profitability. Chandra (2001) argues that organisations having higher liquidity levels are safe and demonstrate strong financial strength.

Nevertheless, the higher level of liquidity enhances financial issues and deteriorates the operational and financial profitability. Eljelly (2004) provides empirical evidence on this nexus. Indicating a negative association between liquidity and profitability, Eljelly (2004) reveals that longer cycles of cash conversions intensify this negative association. ${ }^{5}$ Considering the Pakistani context, we further include the business mix indicator as a bank-specific indicator (BMI). The BMI represents a wide range of business activities, and its linkage with profitability is comparatively new. Existing empirical investigations have mixed and unconvincing evidence on the linkage between BMI and profitability. The generalisability of much published research on this issue is problematic. This substantial difference is expected due to the different estimation techniques, sample period and different countries. Applying revenue diversification, credit portfolio, structure and level of capital, funding and efficiency as the profitability factors, Birindelli et al. (2015) reveal a positive association between the business mix indicators and banks' profitability. However, the net profit margins of the banks decline. Therefore, the banks should focus on the feed-based services to get a competitive advantage and add a new revenue stream into their operations (Ransbotham and Kiron 2017).

Conversely, Tan (2016) reported contradictory evidence from the Chinese banking sector. Using a one-step GMM system estimator, Tan (2016) could not find any evidence on the impacts of the competition and risk on bank profitability (also see Tan et al. 2017; and Tan 2017). Together these empirical pieces of evidence provide essential insights into this nexus that the enhanced product diversification increases the selling options for the organisation and this, in turn, raises the level of the profit margins.

Turning now towards the operational expenses of banks, the existing literature reveals that banking expenses are important profitability determinants. The better management of bank expenses shows the efficiency of bank management. Operationally, efficiency is the ability of the organisation to efficiently

4 For the latest evidences on this nexus, see Santos and Suarez (2019).

5 Eljelly (2004) argues that the cash gap or the cash conversion cycle length are more effective tools to measure liquidity, instead of the current ratio. 
utilise the available resources and generate valuable outcomes through assessing the organisational bottom line. Efficiency ratios, including the return ratio and the margin ratio, evaluate how a company effectively manages and utilises its liabilities and assets, respectively. ${ }^{6}$ In particular, these ratios analyse the organisational turnover of receivables, inventory turnover, fixed assets turnover, and the account payable turnover (Hays et al. 2009). In this context, Bourke (1989) and Molyneux and Thornton (1992) reveal that efficient management accelerates bank profitability. Based on this discussion, we propose the following empirical conjecture.

Empirical Conjecture 1. Bank-specific factors have a significant impact on the profitability of the banking sector of Pakistan.

\subsection{External Determinants of Bank Profitability}

Several lines of evidence suggest that the inflation rate, the long-term interest rate, and the growth rate of money supply are the key macroeconomic determinants of bank profitability (Athanasoglou et al. 2008). Revell (1979) investigates the association between inflation and profitability by comparing the inflation rate with the wage rate and the operating expenses speed. Inflation and interest rates are closely related (see Anari and Kolari 2016), and the interest rate fluctuations posit a critical impact on the profitability of the banks. ${ }^{7}$ Applying two-step GMM estimators, Tan and Floros (2012a) also revealed that there is a positive association between the banking sector profitability, cost efficiency, financial sector development, and inflation in China. The level of the banking spread distribution serves as a crucial indicator of the financial sector efficiency. Institutional, regulatory and macroeconomic factors associate some mandatory costs to the banking operations (Agenor and Flamini 2016).

Furthermore, the internal features also put other costs that banks consume for themselves. In this context, the management efficiency of the costs affects the profitability of the banks. Therefore, banks need to focus on the interest rate indicators of the banks. Analysing the 13 OECD data from 1985 to 1990, Bartholdy et al. (1997) reveal that explicit deposit insurance reduces the level of the deposited interest rates by 25 points. Conversely, Barth et al. (1997) reveal that there is no significant association between the bank concentration, the presence of the (explicit) deposit and the deviance in the banking authority to the return on equity. Beckmann (2007) reveals a negative association between the return on assets and the interest rate. Monetary value also effects the performance of the commercial banks (Akomolafe et al. 2015). Amidu and Wolfe (2008) reveal that money supply and economic indicators affect the lending behaviours of commercial banks in Ghana.

In particular, the bank lending deteriorates the inflation and prime rates of the central banks. The institutional background and the economic conditions of the banks also influence bank profitability. These factors influence the cyclical interest rate and inflation outputs. However, the factors including industry size, the ownership status and the market concentration differ from industry to industry depending on the market conditions (Athanasoglou et al. 2008). Overall, there seems to be some evidence to indicate that the external factors impact the performance of the banks. Gompers and Lerner (1998) affirm that the economies with higher GDP attract the entrepreneurs to invest and launch their ventures. In these economic conditions, the entrepreneurs look for venture funds. In this nexus, interest rates influence the costs of borrowing and demonstrate a significant effect on the return on equity.

Interestingly, Tan and Floros (2012b) reveal a negative relationship between GDP growth and bank profitability. They applied a one-step GMM estimator to test the persistency of the banking sector in China. Based on this discussion, we propose the following empirical conjecture.

6 The margin ratios are concerned with the conversions of the sales dollars into profits. Nevertheless, the returns ratios are used to inculcate the firm's profitability by way of the shareholder's returns.

7 There are two main categories of loan rates, including (1) the interest rates added on the banks, and (2) the depositor's interest rate. The term spread refers to the creation of a distinction between the loan rate and the deposit rate. 
Empirical Conjecture 2. Macroeconomic factors have a significant impact on the profitability of the banking sector of Pakistan.

\section{Data and Variable Construction}

We collected data from 20 commercial banks out of the 36 banks listed on the Pakistani Stock Exchanges (PSX) from 2003 to $2017 .{ }^{8}$ We selected these banks out of the 36 listed banks depending upon the availability of the data on the micro and macro determinants of the profitability. The financial statements of a bank provide a wide range of data on the microeconomic factors. Therefore, we extract the microeconomic factors from the income statement and balance sheets of the respective bank. We used the updated version of the International Financial Statistics to collect the data on macroeconomic variables. Existing literature discusses the suitability of different financial statement variables that can be used to measure the profitability of financial firms, including banks. Marimuthu (2008) reveals that several variables can be used to calculate the profitability of banks. However, the ROA appears as the most appropriate and important one since it covers the operational efficiency of the assets. Similarly, Al-Matari et al. (2014) compares different financial statement components and reveals that ROE efficiently evaluates the profitability and financial performance of banks. We used business mix indicator (BMI), capital adequacy (CA), credit risk (CR), liquidity risk (LR), management efficiency (ME), size (SZ), industrial production (IP), interest rate (IR) and money supply (MS) as the independent variables for this empirical investigation. Based on the existing theoretical and empirical literature, we further categorised these variables into microeconomic and macroeconomic independent variables. We used IP, IR, and MS as the independent macroeconomic variables. However, the rest of the independent variables were used for the microeconomic analysis. We used the following equations to calculate the microeconomic variables, where required:

$$
\begin{gathered}
\text { Business mix indicator }=\frac{\text { Operative Income }}{\text { Total Assets }} \\
\text { Capital Adequacy }=\frac{\text { Total Equity }}{\text { Total Assets }} \\
\text { Credit Risk }=\frac{\text { Imparied Loans (NPL) }}{\text { Gross Loans }} \\
\text { Liquidity Risk }=\frac{\text { Total Loans }}{\text { Customer Deposits }} \\
\text { Management Efficiency }=\frac{\text { Total Cost }}{\text { Income }}
\end{gathered}
$$

We calculated the MBI by applying Equation (1) for all 20 banks over the period ranging from 2003 to 2017. For this purpose, we extracted the operating income and total assets from the financial statement of individual banks. We calculated capital adequacy by using Equation (2) on the financial statement data for the selected banks. We used the data on the non-performing loans in Equation (3) to determine the credit risk. Then, we extended our analysis by calculating the liquidity risk and management efficiency by applying Equations (4) and (5), respectively. We also calculated the size of banks by taking the natural logarithm of total assets of individual banks. We used all these calculated variables as the independent microeconomic variables for this empirical investigation. For the second distinct part, we applied independent macroeconomic variables, including industrial production,

8 These banks include Allied Bank Limited, Askari Bank Limited, Bank Al-Falah Limited, Bank Al-Habib Limited, Bank Islami Limited, Faysal Bank Limited, Habib Bank Limited, Habib Metropolitan Bank Limited, JS Bank Limited, MCB Bank Limited, Meezan Bank Limited, National Bank of Pakistan, Samba Bank Limited, Silk Bank Limited, Soneri Bank Limited, Standard Chartered Bank, Summit Bank Limited, The Bank of Khyber, The Bank of Punjab, United Bank Limited. 
interest rates, and money supply. We retrieved this data from the International Financial Statistics (IFS) dataset published by the International Monetary Fund. The annual data on industrial production are available, and we used the series from 2003 to 2017.

\section{Model Specification and Empirical Strategy}

We present our empirical conjectures in three different equations as follows. First, we included all the microeconomic and macroeconomic variables in Equations (6) and (7). However, the existing empirical literature suggests that there is an overlapping effect of the microeconomic and macroeconomic variables when used in this setting. Therefore, we present different models for the case of microeconomic and macroeconomic variables in Equations (7)-(11), respectively:

$$
\begin{gathered}
R O A_{i, t}=\alpha_{0}+\alpha_{1} R O A_{i, t-1}+\alpha_{2} C A_{i, t}+\alpha_{3} C R_{i, t}+\alpha_{4} M E_{i, t}+\alpha_{5} L R_{i, t}+\alpha_{6} B M_{i, t}+\alpha_{7} S Z_{i, t}+ \\
\alpha_{8} I R_{i, t}+\alpha_{9} M S_{i, t}+\alpha_{10} I P_{i, t}+\varepsilon_{i, t} \\
R O E_{i, t}=\beta_{0}+\beta_{1} R O E_{i, t-1}+\beta_{2} C A_{i, t}+\beta_{3} C R_{i, t}+\beta_{4} M E_{i, t}+\beta_{5} L R_{i, t}+\beta_{6} B M_{i, t}+\beta_{7} S Z_{i, t}+ \\
\beta_{8} I R_{i, t}+\beta_{9} M S_{i, t}+\beta_{10} I P_{i, t}+\varepsilon_{i, t} \\
R O A_{i, t}=\xi_{0}+\xi_{1} R O A_{i, t-1}+\xi_{2} C A_{i, t}+\xi_{3} C R_{i, t}+\xi_{4} M E_{i, t}+\xi_{5} L R_{i, t}+\xi_{6} B M_{i, t}+\xi_{7} S Z_{i, t}+\varepsilon_{i, t} \\
R O E_{i, t}=\lambda_{0}+\lambda_{1} R O E_{i, t-1}+\lambda_{2} C A_{i, t}+\lambda_{3} C R_{i, t}+\lambda_{4} M E_{i, t}+\lambda_{5} L R_{i, t}+\lambda_{6} B M_{i, t}+\lambda_{7} S Z_{i, t}+\varepsilon_{i, t} \\
R O A_{i, t}=\varphi_{0}+\varphi_{1} I R_{i, t}+\varphi_{2} M S_{i, t}+\varphi_{3} I P_{i, t}+\varepsilon_{i, t} \\
R O E_{i, t}=\gamma_{0}+\gamma_{1} I R_{i, t}+\gamma_{2} M S_{i, t}+\gamma_{3} I P_{i, t}+\varepsilon_{i, t}
\end{gathered}
$$

ROA and ROE are the dependent variables, $i$ is a symbol representative of the cross-section, and $\mathrm{t}$ represents the time. ROA, ROE, CA, CR, ME, LR, BM, SZ, IR, MS, and IP represent the return on assets, return on equity, capital adequacy, credit rating, management efficiency, liquidity risk, business mix indicator, size of the bank, interest rate, money supply and industrial production, respectively. The return on assets measures the returns earned through the total assets provided by the owners and creditors. However, the return on equity measures the return earned on the assets provided by owners (See Hoggett et al. 2018). We defined these variables in the Section Data and Variable Construction. We used panel data due to a couple of advantages over other types of datasets (also see Busu 2019). Panel data include many observations from different banks over a different period. This setting also decreases the multicollinearity between the explanatory variables. With greater estimation efficiency, panel data overcome the problems of omitted variables since these variables might be eliminated by taking the difference in the variables which is constant over time (also see Aali-Bujari et al. 2017). In our setting, the return on assets and the return on equity are lagged dependent variables. One of the possible reasons for the lagged dependence can be the fact that operational returns are a mean revert in the long-run due to the partial adjustment. Theoretically, less-profitable companies imitate profitable companies through a couple of techniques-consequently, profitable companies lose their competitive advantage in the long-run.

Similarly, the less profitable companies adopt the best investment strategies and become more profitable in the long run (also see Tongkong 2012). In this context, the estimates from ordinary least squares are subject to bias (Aali-Bujari et al. 2017). ${ }^{9}$ However, the alternative estimation techniques of standard fixed effects are also subject to the Nickell bias (Nickell 1981), particularly in the small T and large N context. Our dataset is in the same context, and Nickell (1981) identifies some severe difficulties with the one-way fixed effects. This difficulty mainly arises since the demeaning process, which subtracts the variables' mean value of dependent and each independent from the respective set of variables, creates a correlation between regressor and residual.

9 For further details, see Beaver and Ryan (2000). 
There might be autocorrelation in the residuals of Equations (6) and (7). We should carefully model this autocorrelation and dynamic data-generating process to arrive at unbiased and consistent estimates. For this purpose, Anderson and Hsiao (1981) suggest using lags of explained variables as an instrument where these lags are uncorrelated with the residuals. In our framework, we can also use the alternative measures of profitability as an instrument variable in the instrumental variable estimation. Furthermore, some exogenous variables work well as an instrument in this dynamic panel data estimation (see Song et al. 2019; and Dan Dang 2019). Cameron and Trivedi (2010) reveal that the model error under Arellano/Bover or Blundell/Bond should be serially uncorrelated. ${ }^{10}$ However, sometimes the model errors are serially correlated, which we observed during our initial data analysis. Cameron and Trivedi (2010) suggest adding more lags of the dependent variables as the regressors, which eliminate any serial correlation in the error. For this type of estimation, dynamic panel data estimation is suggested which allows the error term to follow a moving average process of low order. In particular, dynamic panel data estimation allows predetermined variables for more complicated structures. We applied dynamic panel data in the Arellano and Bond (Arellano and Bond 1991) framework.

\section{Empirical Results and Discussion}

\subsection{Descriptive Statistics and Correlation Analysis}

A critical review of Table 1 reveals that management efficiency has the highest level of deviation in all three categories, including overall, between and within. Equation (5) shows that management efficiency is the ratio of cost and income. This gap indicates the operational efficiency of management and the highest level of variation $(\mathrm{M}=2.91 ; \mathrm{SD}=5.60)$ originates within the banks. This might be due to the seasonal variation in the banking operations, which might be subject to the cyclical change in the banking behaviour of the developing economies. ${ }^{11}$

Looking at the macroeconomic indicators, we observed that the interest rates are highly volatile $(\mathrm{M}=8.72 ; \mathrm{SD}=3.82)$ due to the demand pressure over the last couple of decades (Shah et al. 2010; Akhtar 2007; Subayyal and Shah 2011). We also observe a slight variation in the money supply from 2003 to $2017(\mathrm{M}=2.74 ; \mathrm{SD}=0.40)$. In this context, Khan et al. (2007) reveals that the government sector borrowing and private sector borrowings are the two main categories of asset sides of the money supply. This variation might be due to the change in these asset classes from 2003 to 2017. Looking at the macroeconomic indicators, we observed that the interest rates are highly volatile $(\mathrm{M}=8.72$; $\mathrm{SD}=3.82$ ) due to the demand pressure over the last couple of decades (Shah et al. 2010; Akhtar 2007; Subayyal and Shah 2011).

We also observed a slight variation in the money supply from 2003 to $2017(\mathrm{M}=2.74 ; \mathrm{SD}=0.40)$. Similarly, Khan et al. (2007) reveals that government sector borrowing and private sector borrowings are two main categories of asset sides of the money supply. This variation might be due to the change in these asset classes from 2003 to 2017. However, we observe a lower level of change in industrial production $(\mathrm{M}=1.14 ; \mathrm{SD}=0.05)$, which might be since the financial sector observes more attention compared to the real sector. ${ }^{12}$ Turning now to the range value of microeconomic and macroeconomic indicators, Table 1 reveals that all financial statement variables except the size of the banks have the negative values in their minimum range which is consistent with the theory. We also examine the data normality through the kurtosis and skewness. Rosli et al. (2016) notify that the data are revealed as normal if the value of skewness is between +1.96 and -1.96 . The kurtosis is affirmed in the normal ranges if the value is the range from +2 to -2 . We ensured that our data were normally distributed.

10 For further details, See Section 9.4.8 The xtdpd command from Chapter 9 Linear Panel-Data Methods: Extensions.

11 This variation is expected to change between the small and large banks. However, we include the size of banks as a control variable.

12 For further details, see Mordi (2010). 
We noticed that the money supply and management efficiency had the highest skewness values of 1.951 and 1.765, respectively. Conversely, the interest rate and size have the lowest skewness values of -0.431 and 10.714 , respectively. These values indicate that the skewness lies between the standard ranges from +2 to -2 (Rosli et al. 2016). We ensured that the data were normally distributed.

Table 1. Descriptive statistics (overall, between, and within).

\begin{tabular}{|c|c|c|c|c|c|}
\hline Variable & Categories & Mean & SD & Min & Max \\
\hline \multicolumn{6}{|c|}{ Microeconomic Indicators } \\
\hline \multirow[t]{3}{*}{ ROA } & Overall & 0.0074 & 0.0172 & -0.0719 & 0.0372 \\
\hline & Between & & 0.0121 & -0.0281 & 0.0268 \\
\hline & Within & & 0.0125 & -0.0475 & 0.0441 \\
\hline \multirow[t]{3}{*}{ ROE } & Overall & 0.0580 & 0.9556 & -14.7427 & 2.3472 \\
\hline & Between & & 0.3593 & -1.3600 & 0.2777 \\
\hline & Within & & 0.8888 & -13.3246 & 2.3172 \\
\hline \multirow[t]{3}{*}{ Size } & Overall & 2.9487 & 0.0678 & 2.7385 & 3.0713 \\
\hline & Between & & 0.0576 & 2.8266 & 3.0299 \\
\hline & Within & & 0.0378 & 2.8117 & 3.0427 \\
\hline \multirow[t]{3}{*}{$\mathrm{CA}$} & Overall & 0.0922 & 0.0808 & -0.0310 & 0.5432 \\
\hline & Between & & 0.0584 & 0.0262 & 0.2310 \\
\hline & Within & & 0.0572 & -0.1225 & 0.4123 \\
\hline \multirow[t]{3}{*}{ CR } & Overall & 0.1144 & 0.1055 & 0.0001 & 0.6305 \\
\hline & Between & & 0.0710 & 0.0173 & 0.2969 \\
\hline & Within & & 0.0796 & -0.0963 & 0.4480 \\
\hline \multirow[t]{3}{*}{$\mathrm{ME}$} & Overall & 2.9134 & 5.7729 & -12.2772 & 53.8965 \\
\hline & Between & & 1.4427 & 1.0964 & 6.0914 \\
\hline & Within & & 5.5984 & -11.4364 & 55.6083 \\
\hline \multirow[t]{3}{*}{ LR } & Overall & 0.5374 & 0.1207 & 0.1888 & 0.8934 \\
\hline & Between & & 0.0716 & 0.3473 & 0.6516 \\
\hline & Within & & 0.0984 & 0.3226 & 0.8266 \\
\hline \multirow[t]{3}{*}{ BMI } & Overall & 0.0004 & 0.0004 & 0.0000 & 0.0022 \\
\hline & Between & & 0.0002 & 0.0002 & 0.0010 \\
\hline & Within & & 0.0003 & -0.0005 & 0.0017 \\
\hline \multicolumn{6}{|c|}{ Macroeconomic Indicators } \\
\hline IR & & 8.7250 & 3.3823 & 1.8700 & 13.1200 \\
\hline MS & & 2.7386 & 0.4041 & 1.8800 & 3.8200 \\
\hline $\mathrm{IP}$ & & 1.1357 & 0.0483 & 1.0600 & 1.2400 \\
\hline
\end{tabular}

Note. $\mathrm{N}, \mathrm{n}$, and T are 300, 20, and 15, respectively. ROA, ROE, CA, CR, ME, LR, BMI, IR, MS, and IP represent the return on assets, return on equity, capital adequacy, credit rating, management efficiency, liquidity risk, business mix indicator, interest rate, money supply and industrial production, respectively.

We further extended our empirical investigation by conducting a correlation analysis. For this purpose, we applied the Pearson correlation and presented the correlation coefficient along with its statistical significance in Table 2. First, we made sure that the independent variables were not highly correlated with each other, which created the problem of multicollinearity (see Willis and Perlack 1978; Mansfield and Helms 1982). Multicollinearity increases the variance of estimated coefficients, and this enhanced variance makes these estimates very sensitive to the minor changes in the model. ${ }^{13}$ Table 2 is quite revealing in several ways. Column 3 of Table 3 reveals some of the critical results. In particular, Column 3 indicates that the size of banks has the highest level of correlation with capital adequacy $\left(\rho_{\text {size,ca }}=-0.6082 ; p<0.05\right)$. Equation (2) reveals that capital adequacy is a ratio between the total equity and total asset. This indicates the owner's interest in the total worth of business which should

13 For further details on multicollinearity, see (Yoo et al. 2014). 
be theoretically associated with the total assets of the company. However, this number is not expected to create serious concerns about multicollinearity.

Table 2. Correlation analysis.

\begin{tabular}{|c|c|c|c|c|c|c|c|c|c|c|c|}
\hline & ROA & ROE & Size & CA & CR & ME & LR & BMI & IR & LMS & IP \\
\hline ROA & $\begin{array}{c}1.00 \\
-\end{array}$ & & & & & & & & & & \\
\hline ROE & $\begin{array}{c}0.40^{*} \\
0.00\end{array}$ & $\begin{array}{c}1.00 \\
-\end{array}$ & & & & & & & & & \\
\hline Size & $\begin{array}{c}0.45^{*} \\
0.00\end{array}$ & $\begin{array}{c}0.15^{*} \\
0.01\end{array}$ & $\begin{array}{c}1.00 \\
-\end{array}$ & & & & & & & & \\
\hline CA & -0.10 & 0.03 & $\underset{*}{-0.6082}$ & 1.00 & & & & & & & \\
\hline CR & $\begin{array}{c}0.11 \\
-0.66 \text { * } \\
0.00\end{array}$ & $\begin{array}{c}0.66 \\
-0.21 \text { * } \\
0.00\end{array}$ & $\begin{array}{c}0.00 \\
-0.26^{*} \\
0.00\end{array}$ & $\begin{array}{l}- \\
0.07 \\
0.24\end{array}$ & $\begin{array}{c}1.00 \\
-\end{array}$ & & & & & & \\
\hline $\mathrm{ME}$ & $\begin{array}{l}0.05 \\
0.44\end{array}$ & $\begin{array}{l}0.05 \\
0.42\end{array}$ & $\begin{array}{l}0.07 \\
0.22\end{array}$ & $\begin{array}{c}-0.07 \\
0.21\end{array}$ & $\begin{array}{c}-0.04 \\
0.50\end{array}$ & $\begin{array}{c}1.00 \\
-\end{array}$ & & & & & \\
\hline LR & $\begin{array}{c}-0.17 \text { * } \\
0.00\end{array}$ & $\begin{array}{c}-0.09 \\
0.14\end{array}$ & $\begin{array}{c}-0.23 \\
0.00\end{array}$ & $\begin{array}{l}0.10 \\
0.10\end{array}$ & $\begin{array}{l}0.02 \\
0.69\end{array}$ & $\begin{array}{l}0.01 \\
0.81\end{array}$ & $\begin{array}{c}1.00 \\
-\end{array}$ & & & & \\
\hline BMI & $\begin{array}{c}-0.45 \text { * } \\
0.00\end{array}$ & $\begin{array}{c}-0.26 \\
0.00\end{array}$ & $\begin{array}{c}-0.16^{*} \\
0.01\end{array}$ & $\begin{array}{c}0.15^{*} \\
0.01\end{array}$ & $\begin{array}{c}0.39 * \\
0.00\end{array}$ & $\begin{array}{c}-0.36^{*} \\
0.00\end{array}$ & $\begin{array}{c}0.25^{*} \\
0.00\end{array}$ & $\begin{array}{c}1.00 \\
-\end{array}$ & & & \\
\hline IR & $\begin{array}{c}-0.08 \\
0.16\end{array}$ & $\begin{array}{c}-0.12 \\
0.05\end{array}$ & $\begin{array}{c}0.23 \\
0.00\end{array}$ & $\begin{array}{c}-0.01 \\
0.83\end{array}$ & $\begin{array}{l}0.05 \\
0.40\end{array}$ & $\begin{array}{l}0.09 \\
0.13\end{array}$ & $\begin{array}{c}0.14 \text { * } \\
0.02\end{array}$ & $\begin{array}{c}-0.04 \\
0.51\end{array}$ & $\begin{array}{c}1.00 \\
-\end{array}$ & & \\
\hline LMS & $\begin{array}{l}0.06 \\
0.35\end{array}$ & $\begin{array}{l}0.01 \\
0.88\end{array}$ & $\begin{array}{c}-0.20 * \\
0.00\end{array}$ & $\begin{array}{l}0.05 \\
0.42\end{array}$ & $\begin{array}{c}-0.03 \\
0.59\end{array}$ & $\begin{array}{c}-0.16^{*} \\
0.01\end{array}$ & $\begin{array}{l}0.03 \\
0.60\end{array}$ & $\begin{array}{l}0.12 \\
0.05\end{array}$ & $\begin{array}{c}-0.27^{*} \\
0.00\end{array}$ & $\begin{array}{c}1.00 \\
-\end{array}$ & \\
\hline IP & $\begin{array}{c}-0.11 \\
0.07\end{array}$ & $\begin{array}{c}-0.16^{*} \\
0.01\end{array}$ & $\begin{array}{c}-0.09 \\
0.13\end{array}$ & $\begin{array}{l}0.04 \\
0.46\end{array}$ & $\begin{array}{l}0.02 \\
0.79\end{array}$ & $\begin{array}{l}0.01 \\
0.85\end{array}$ & $\begin{array}{c}0.27^{*} \\
0.00\end{array}$ & $\begin{array}{l}0.08 \\
0.17\end{array}$ & $\begin{array}{c}0.52 * \\
0.00\end{array}$ & $\begin{array}{l}0.07 \\
0.26\end{array}$ & $\begin{array}{c}1.00 \\
-\end{array}$ \\
\hline
\end{tabular}

Note. ${ }^{*}$ indicates significance at the 5 percent level of significance.

Table 3. Panel unit root tests.

\begin{tabular}{|c|c|c|c|c|}
\hline & \multicolumn{2}{|c|}{ Levin-Lin-Chu Test } & \multicolumn{2}{|c|}{ Hadri LM Test } \\
\hline & (1) & (2) & (3) & (4) \\
\hline & $t$-Statistics & $p$-Value & $z$-Statistics & $p$-Value \\
\hline ROA & -15.8812 & 0.0000 & 10.9458 & 0.0000 \\
\hline ROE & -5.4712 & 0.0000 & 2.361 & 0.0091 \\
\hline Size & -4.288 & 0.0000 & 7.9428 & 0.0000 \\
\hline CA & -5.0845 & 0.0000 & 14.0118 & 0.0000 \\
\hline CR & -6.3695 & 0.0000 & 12.8755 & 0.0000 \\
\hline $\mathrm{ME}$ & -80.1401 & 0.0000 & 3.22000 & 0.0000 \\
\hline LR & -4.4801 & 0.0000 & 11.5314 & 0.0000 \\
\hline BMI & -15.373 & 0.0000 & 9.3278 & 0.0000 \\
\hline IR & -5.5764 & 0.0000 & 23.805 & 0.0000 \\
\hline MS & -10.8296 & 0.0000 & -2.6107 & 0.9955 \\
\hline IP & 0.1755 & 0.5697 & 8.7058 & 0.0000 \\
\hline
\end{tabular}

Note. We report adjusted t-statistics for the Levin-Lin-Chu unit root test. Levin-Lin-Chu Hypotheses: Ho: Panels contain unit roots. Ha: Panels are stationary. LR variance: Bartlett kernel, 7.00 lags average (chosen by Levin-Lin-Chu (LLC)). Hadri LM Test Hypotheses: Ho: All panels are stationary. Ha: Some panels contain unit-roots.

Turning now towards the macroeconomic variables, Column 9 to 11 present the correlation coefficient along with its statistical significance of the macroeconomic variables, including interest rates, money supply and industrial production. Interest rates have a moderate level of correlation with industrial production $\left(\rho_{\mathrm{IR}, \mathrm{IP}}=-0.52 ; p<0.05\right)$. However, this number is below the suggested benchmark for multicollinearity (see Haitovsky 1969). Correlation analysis reveals that all independent variables can be used in the regression analysis and the estimated coefficients are not subject to any sensitivity.

It can be seen from the correlation analysis that returns on the asset has a statistically significant correlation with the credit rating $\left(\rho_{\mathrm{ROA}, \mathrm{CR}}=-0.52 ; p<0.05\right)$, however, the direction of this relationship 
is not clear. Credit rating might be affected due to the return on assets which is expected to create the issue of endogeneity. To prevent the potential consequences of endogeneity, we applied dynamic panel data estimation to obtain the unbiased and consistent estimate in this setting of our banking, as well as financial and economic variables (Chenhall and Moers 2007; Van Lent 2007). Interestingly, the return on assets and the return on equity are correlated $\left(\rho_{\mathrm{ROA}, \mathrm{ROE}}=0.40 ; p<0.05\right)$ which makes sense in terms of accounting since the equity is an integral part of the total size of the banking business.

\subsection{Panel Unit Root Tests}

Nelson and Plosser (1982) initially pointed out the issue of a unit root in the aggregated time series data. Later, the procedure of the unit root test became the necessary procedure for any economic analysis (Nelson and Plosser 1982; Huang et al. 2008). In panel data analysis, the panel unit root test is necessary to identify the stationary properties of the variables. Several panel unit root tests can be applied. We apply the Levin-Lin-Chu (LLC) and Hadri LM tests to ensure the robustness of the results (Levin et al. 2002; Hadri 2000). ${ }^{14}$ Table 3 presents the result of the panel unit root test for each variable. Column 1 and 2 of Table 3 show the results of the Levin-Lin-Chu panel unit root test.

Similarly, Column 3 and 4 of Table 3 present the results of the Hadri LM panel unit root test. In Table 3, there is a piece of clear evidence that ROA, ROE, Size, CA, CR, ME, LR, BMI, and IR are statistically significant at the $5 \%$ level of significance which reveals that these variables are stationary at the level. However, we found contradictory results for the case of MS and IP. Due to these conflicting results, we estimated Equations (6), (7), (10), and (11) in both forms to avoid any over-differencing problem. However, we ensured that all variables used in the dynamic panel estimation is stationary at the level. ${ }^{15}$

\subsection{Dynamic Panel Data Estimation}

Table 4 presents the dynamic panel data estimates from Equations (6)-(11). Column 1 and 2 of Table 4 present the dynamic panel data estimation of all the (bank-specific and macroeconomic) determinants using ROA and ROE as a measure of profitability, respectively. Column 3 and 4 of Table 4 presents the dynamic panel data estimation of bank-specific determinants using ROA and ROE as a measure of profitability, respectively. Column 5 and 6 presents the dynamic panel data estimation of macroeconomic determinants using ROA and ROE as a measure of profitability, respectively.

The dynamic panel data estimates of Equations (6) and (7) reveal that none of the variables affect the bank profitability in Pakistan. More specifically, the bank size $\left(\alpha_{7}=-0.2710 ; p>0.05\right)$, capital adequacy $\left(\alpha_{2}=0.3090 ; p>0.05\right)$, credit rating $\left(\alpha_{3}=-0.2850 ; p>0.05\right)$, management efficiency $\left(\alpha_{4}=-0.0019\right.$; $p>0.05)$, liquidity ratio $\left(\alpha_{5}=-0.1290 ; p>0.05\right)$, and business mix indicator $\left(\alpha_{6}=-115.5000 ; p>0.05\right)$ have no impact on the return on assets of the banking sector of Pakistan. These findings are consistent with the Kosmidou (2008). The economic theory reveals that bank profitability might be subject to economics or diseconomies of the scale. The internal determinant, bank size, accounts for the economies or diseconomies of scale (Shepherd 1972). For the case of the Pakistani banking industry, none of the effect is dominating. Furthermore, the production capacity of the bank, the numerous services the bank provides, the quality and quantity of services that the banks may offer to its prospects at a given time, determines the size of the banks (Sritharan 2015).

14 Unit root tests are also a necessary procedure for the panel data analysis. See Levin et al. (2002) for the further details on the asymptotic and finite-sample properties for the case of the panel unit root.

15 In the case of contradictory results, we ensured that the variables must be stationary at least under one criterion. 
Table 4. Impact of bank-specific and macroeconomic determinants on financial performance-ArellanoBond Framework.

\begin{tabular}{|c|c|c|c|c|c|c|}
\hline & ROA & ROE & ROA & ROE & ROA & ROE \\
\hline & (1) & (2) & (3) & (4) & (5) & (6) \\
\hline SZ & $\begin{array}{c}-0.2710 \\
(-0.82)\end{array}$ & $\begin{array}{c}-12.8400 \\
(-0.52)\end{array}$ & $\begin{array}{c}0.0088 \\
(0.17)\end{array}$ & $\begin{array}{c}-0.2580 \\
(-0.04)\end{array}$ & & \\
\hline CA & $\begin{array}{c}0.3090 \\
(1.03)\end{array}$ & $\begin{array}{c}16.3600 \\
(0.73)\end{array}$ & $\begin{array}{c}0.4030 * * \\
(3.17)\end{array}$ & $\begin{array}{c}20.6700 \\
(1.41)\end{array}$ & & \\
\hline CR & $\begin{array}{c}-0.2850 \\
(-1.10)\end{array}$ & $\begin{array}{c}-17.1000 \\
(-0.88)\end{array}$ & $\begin{array}{c}-0.0322 \\
(-0.63)\end{array}$ & $\begin{array}{c}-7.4970 \\
(-1.27)\end{array}$ & & \\
\hline $\mathrm{ME}$ & $\begin{array}{c}-0.0019 \\
(-0.72)\end{array}$ & $\begin{array}{c}-0.1440 \\
(-0.74)\end{array}$ & $\begin{array}{c}-0.0009 \\
(-0.95)\end{array}$ & $\begin{array}{c}-0.1100 \\
(-1.03)\end{array}$ & & \\
\hline LR & $\begin{array}{c}-0.1290 \\
(-1.47)\end{array}$ & $\begin{array}{c}-3.9410 \\
(-0.60)\end{array}$ & $\begin{array}{c}-0.0784^{* *} \\
(-3.03)\end{array}$ & $\begin{array}{c}-1.4140 \\
(-0.47)\end{array}$ & & \\
\hline BMI & $\begin{array}{c}-115.5000 \\
(-1.32)\end{array}$ & $\begin{array}{c}-78.7350 \\
(-1.20)\end{array}$ & $\begin{array}{c}-30.0900 \\
(-1.66)\end{array}$ & $\begin{array}{c}-47.7850 * \\
(-2.28)\end{array}$ & & \\
\hline IR & $\begin{array}{c}0.002170 \\
(1.01)\end{array}$ & $\begin{array}{c}0.08950 \\
(0.56)\end{array}$ & & & $\begin{array}{c}-0.0005^{* *} \\
(-3.09)\end{array}$ & $\begin{array}{c}-0.0419 \\
(-1.92)\end{array}$ \\
\hline LMS & $\begin{array}{c}0.0014 \\
(0.25)\end{array}$ & $\begin{array}{c}-0.0138 \\
(-0.03)\end{array}$ & & & $\begin{array}{c}0.0012 \\
(1.08)\end{array}$ & $\begin{array}{c}-0.0818 \\
(-0.54)\end{array}$ \\
\hline IP & $\begin{array}{c}0.00680 \\
(0.24)\end{array}$ & $\begin{array}{c}-0.0581 \\
(-0.03)\end{array}$ & & & $\begin{array}{c}-0.0151 \text { * } \\
(-2.17)\end{array}$ & $\begin{array}{c}-1.4430 \\
(-1.54)\end{array}$ \\
\hline$C$ & $\begin{array}{c}0.9130 \\
(0.86)\end{array}$ & $\begin{array}{l}43.49 \\
(0.55)\end{array}$ & $\begin{array}{c}0.00540 \\
(0.03)\end{array}$ & $\begin{array}{c}2.8950 \\
(0.16)\end{array}$ & $\begin{array}{c}0.0085 \text { * } \\
(2.25)\end{array}$ & $\begin{array}{c}0.6530 \\
(1.28)\end{array}$ \\
\hline $\begin{array}{c}\text { Sargan Test } \\
\text { Test-statistics } \\
\text { (p-values) }\end{array}$ & $\begin{array}{c}0.253 \\
0.9686\end{array}$ & $\begin{array}{l}0.3793 \\
0.9445\end{array}$ & $\begin{array}{l}7.0889 \\
0.3127\end{array}$ & $\begin{array}{l}1.4089 \\
0.9653\end{array}$ & $\begin{array}{c}316.23 \\
1.00\end{array}$ & $\begin{array}{l}11.177 \\
0.2638\end{array}$ \\
\hline $\begin{array}{c}\mathrm{AR}(1) \\
(z, p \text {-value })\end{array}$ & $\begin{array}{c}-5.6717 \\
0.0000\end{array}$ & $\begin{array}{c}-7.8577 \\
0.0000\end{array}$ & $\begin{array}{c}-5.3995 \\
0.0000\end{array}$ & $\begin{array}{c}-8.8993 \\
0.0000\end{array}$ & $\begin{array}{c}-8.6928 \\
0.0000\end{array}$ & $\begin{array}{c}-10.5770 \\
0.0000\end{array}$ \\
\hline $\begin{array}{c}\mathrm{AR}(2) \\
(z, p \text {-value })\end{array}$ & $\begin{array}{c}-1.3398 \\
0.1803\end{array}$ & $\begin{array}{l}1.5516 \\
0.1208\end{array}$ & $\begin{array}{c}-1.3947 \\
0.1631\end{array}$ & $\begin{array}{c}0.84651 \\
0.3973\end{array}$ & $\begin{array}{c}-1.1889 \\
0.2345\end{array}$ & $\begin{array}{l}2.3983 \\
0.1650\end{array}$ \\
\hline $\mathrm{N}$ & 260 & 260 & 280 & 280 & 260 & 260 \\
\hline
\end{tabular}

Note. ${ }^{*}$ and ${ }^{* *}$ indicate significance at $10 \%$ and $5 \%$ t-statistics in parentheses.

Then, we extend our analysis on the return on equity as a measure of the financial performance of the Pakistani banking sector. These results also indicate that bank size $\left(\beta_{7}=-12.8400 ; p>0.05\right)$, capital adequacy $\left(\beta_{2}=16.3600 ; p>0.05\right)$, credit rating $\left(\beta_{3}=-17.1000 ; p>0.05\right)$, management efficiency $\left(\beta_{4}=-0.1440 ; p>0.05\right)$, liquidity ratio $\left(\beta_{5}=-3.9410 ; p>0.05\right)$, and business mix indicator $\left(\beta_{6}=-78.7350 ; p>0.05\right)$ do not affect the return on equity of the banking sector of Pakistan. Again, we find the similar evidences on the bank size where none of the effect is dominating (Kosmidou 2008; Shepherd 1972). These results of consistent with the contemporary research (Athanasoglou et al. 2008) indicate that bank-specific and macroeconomic variables should be not included in a single equation due to the overlapping effect. There is a possibility that the estimated standard errors of these estimates are greater than the true standard error and the estimated test-statistics falls under the non-rejection region.

Therefore, we extended this analysis from Equations (8)-(11). Column 3 and 4 of Table 4 present the results of bank-specific determinants of bank profitability. The most striking result to emerge from the data is that capital adequacy $\left(\xi_{2}=0.4030 ; p<0.05\right)$ accelerates the profitability of the banking sector in Pakistan (Ogboi and Unuafe 2013). Capital structure plays a critical role for any firm by providing an opportunity to increase the organisational profitability and the overall value of an organisation. One of the possible reasons for this positive impact is the fact that capital structure decisions are critical for the banks. These decisions provide them with an opportunity to boost up their profit margins and combat with the stiff market competition (Abor 2005; Nikoo 2015; Umar et al. 2012; Salteh et al. 2012; 
Arbabiyan and Safari 2009). Generally, the capital adequacy ratio is considered safe, and it is more likely that banks meet their financial obligations. Theoretically, this leads to the profitability of the banks. Capital adequacy helps the banking system and regulators to absorb any negative shock in the financial and economic system. In a similar vein, capital adequacy also helps in mitigating the number of bank failures and losses (Almazari 2013). This evidence is consistent with the existing empirical literature (Ogboi and Unuafe 2013; Abor 2005; Nikoo 2015; Umar et al. 2012; Salteh et al. 2012; Arbabiyan and Safari 2009). There is no empirical evidence from the bank-specific analysis that bank size $\left(\xi_{7}=0.0088 ; p>0.05\right)$, credit rating $\left(\xi_{3}=-0.0322 ; p>0.05\right)$, management efficiency $\left(\xi_{4}=-0.0009 ; p>0.05\right)$ and business mix indicator $\left(\xi_{6}=-30.0900 ; p>0.05\right)$ have an impact on the return on assets of the banking sector of Pakistan. These results contrast with the existing literature (Bourke 1989; Molyneux and Thornton 1992; and Birindelli et al. 2015). Furthermore, this analysis reveals that the liquidity ratio $\left(\xi_{5}=-0.0784 ; p<0.05\right)$ deteriorates the financial performance of the Pakistani banking sector. These results are consistent with the theory and empirical evidence (Molyneux and Thornton 1992).

In the banking sector, liquidity risks transmit into the unpaid loans and hence the lower return. Equation (4) further suggests that the liquidity risk is the ratio of total loans and customer deposits. The higher liquidity risk puts pressure on the total amount of recovery. In particular, the higher liquidity risk will enhance the probability of default on the loans. Therefore, the higher liquidity risk deteriorates the financial performance of the Pakistani banking sector. The insignificant results of the bank size reveal that we have no evidence that Pakistani banks are availing any benefit of the economies of scale (Mamatzakis and Remoundos 2003). This might be due to the intense competition in the Pakistani banking sector (Bhatti and Hussain 2010). The next section of this empirical investigation is about the impact of bank-specific indicators on the return on equity for the banking sector of Pakistan. We find no empirical evidence that bank size $\left(\lambda_{7}=-0.2580 ; p>0.05\right)$, capital adequacy $\left(\lambda_{2}=20.6700\right.$; $p>0.05)$, credit rating $\left(\lambda_{3}=-7.4970 ; p>0.05\right)$, management efficiency $\left(\lambda_{4}=-0.1100 ; p>0.05\right)$, and liquidity ratio $\left(\lambda_{5}=-1.4140 ; p>0.05\right)$ have an impact on the return on equity of the banking sector of Pakistan. These results are consistent with the existing literature (Abor 2005; Nikoo 2015; Umar et al. 2012; Salteh et al. 2012; Arbabiyan and Safari 2009). However, this component of the dynamic panel data investigation reveals that the business mix indicator $\left(\lambda_{6}=-47.7850 ; p<0.10\right)$ deteriorates the return on equity through enhancing the selling options for the organisation when diversification increases. This phenomenon, in turn, raises the level of the profit margins.

Turning now to the macroeconomic variables, our results indicate that the interest rate $\left(\varphi_{1}=-0.0005\right.$; $p<0.05)$ and industrial production $\left(\varphi_{3}=-0.0151 ; p<0.10\right)$ deteriorate the return on assets of the banking sector of Pakistan. However, we could not find any pieces of evidence on the linear relationship between money supply $\left(\varphi_{2}=0.0012 ; p>0.05\right)$ and the financial performance of the banking sector of Pakistan. Our results further reveal that the interest rate $\left(\gamma_{1}=-0.0419 ; p>0.05\right)$, money supply $\left(\gamma_{2}=-0.0818 ; p>0.05\right)$, and industrial production $\left(\gamma_{3}=-1.4430 ; p>0.05\right)$ have no impact on the return on equity of the banking sector of Pakistan. Our results are consistent with the existing empirical literature (Akomolafe et al. 2015; Beckmann 2007). For the estimates of all Equations from (6) to (11), we provided the values of the Sargan Test and Arellano-Bond test. The Sargan test indicates that there was no evidence of over-identifying restrictions. The AR (1) and AR (2) values reveal that the first-order autocorrelation is negative and statistically significant at 1 percent level of significance. However, the second-order autocorrelation is insignificant (See Table 4). These results indicate that our estimates are consistent.

Overall, these findings suggest that the managers should carefully take capital decisions since these decisions provide them with an opportunity to lift their profit margins. The managers should develop effective policies to ensure the reduction in the level of non-performing loans. Furthermore, the government needs to formulate stringent strategies that influence the banks to increase the number of assets and the capital base. Looking at the product lines, the banks should enhance their number of products that will eventually raise their profit margins. Furthermore, these findings reveal that the 
regulatory bodies and the State Bank of Pakistan should develop a robust mechanism to control the interest rates. This study is limited to the credit risk, liquidity risk, management efficiency, capital adequacy and the business mix indicator that works as the determinant of bank's profitability. Hence, this study is limited to the banking sector of Pakistan and carefully implemented on other components of the financial system. These results are based on the financial statement data and accounting measures. However, accounting data are prepared in the standardised procedures, which may leave out qualitative aspects. Besides, accounting ratios may not represent the current situation of the profitability of the banking sector.

\section{Limitations and Future Research}

This research has some limitations. The profitability of a financial sector can be measured through a wide range of gauges. However, this research focuses on the credit risk, liquidity risk, management efficiency, capital adequacy and the business mix indicator. Furthermore, we only included the banking sector of Pakistan. These indicators are calculated through the financial ratio formulas using the data obtained from financial statements. However, accounting data were prepared in standardised procedures, which may leave out qualitative aspects. In addition, accounting ratios may not represent the current situation of the profitability of the banking sector. To develop the full picture of the profitability, further studies are needed that include other gauges of the profitability including the net profit margin and net interest margin. Future research should include the non-banking components of the financial sector of Pakistan. The profitability behaviour of the Islamic banking sector might be different in Pakistan due to the religious affiliation of the customers.

\section{Conclusions}

The objective of this study was to evaluate the impact of bank-specific and macro-economic determinants of the profitability of the banking sector of Pakistan. For the bank-specific analysis, we collected the data from the financial statements of 20 banks ranging the period from 2003 to 2017 . For the macro-economic analysis, we retrieved the data from the International Financial Statistics (IFS) dataset published by the International Monetary Fund. We applied a generalised method of moments (GMM) technique under the Arellano-Bond framework to a panel of Pakistani banks. The results of this empirical investigation reveal that capital adequacy accelerates the profitability of the banking sector of Pakistan. This indicates that capital structure decisions are crucial for the management of banks. In this way, the bankers can boost their profit margins and combat with the stiff market competition. The higher proportion of equity also helps the banking system to soak up any negative shock in the financial and economic system. Conversely, our empirical investigation reveals that the liquidity ratio, business mix indicators, interest rates, and industrial production deteriorates the bank profitability. Enhancing the probability of the default risk, the liquidity risks transmit into the unpaid loans and hence lower the return.

Author Contributions: All authors contributed to the entire process of writing this paper. H.R. wrote the original draft; all authors reviewed and edited the draft. All authors have read and agreed to the published version of the manuscript.

Funding: This research received no external funding.

Conflicts of Interest: The authors declare no conflict of interest.

\section{References}

Aali-Bujari, Ali, Francisco Venegas-Martinez, and Omar Palafox-Roca. 2017. Impact of energy consumption on economic growth in major OECD economies (1977-2014): A panel data approach. International Journal of Energy Economics and Policy 7: 18-25.

Abdel-Jalil, Tawfiq. 2014. The impact of capital structure on the performance of the Jordanian publicly-held industrial companies. Jordan Journal of Business Administration 10: 390-403. 
Abor, Joshua. 2005. The effect of capital structure on profitability: An empirical analysis of listed firms in Ghana. The Journal of Risk Finance 6: 438-45. [CrossRef]

Adrian, Tobias, and Huan Shin. 2008. Liquidity and financial contagion. Banque de France Financial Stability Review: Special Issue on Liquidity 11: 1-7.

Aduda, Josiah, and James Gitonga. 2011. The relationship between credit risk management and profitability among the commercial banks in Kenya. Journal of Modern Accounting and Auditing 7: 934.

Agenor, Pierre-Richard, and Alessandro Flamini. 2016. Institutional Mandates for Macroeconomic and Financial Stability. Centre for Growth and Business Cycle Research Discussion Paper Series 231; Manchester: The Univeristy of Manchester.

Akhtar, Shamshad. 2007. Pakistan: Changing risk management paradigm-perspective of the regulator. Paper presented at the ACCA Conference-CFOs: The Opportunities and Challenges Ahead, Karachi, Pakistan, March 13; p. 8.

Akomolafe, Kehinde Jhon, Jonathan D. Danladi, Olodapo Babalola, and Austin G. Abah. 2015. Monetary policy and Commercial banks' performance in Nigeria. Public Policy and Administration Research 5: 158-66.

Allen, Franklin, and Douglas Gale. 2004. Financial intermediaries and markets. Econometrica 72: $1023-61$. [CrossRef]

Allen, Franklin, and Anthony M. Santomero. 2001. What do financial intermediaries do? Journal of Banking $\mathcal{E}$ Finance 25: 271-94.

Al-Matari, Ebrahim Mohammed, Abdullah Kaid Al-Swidi, and Hanim Bt Fadzil. 2014. The measurements of firm performance's dimensions. Asian Journal of Finance $\mathcal{E}$ Accounting 6: 24-49.

Almazari, Ahmed Aref. 2013. Capital adequacy, cost-income ratio and the performance of Saudi banks. International Journal of Academic Research in Accounting, Finance and Management Sciences 3: 284-93.

Al-Taani, Khalaf. 2013. The relationship between capital structure and firm performance: Evidence from Jordan. Journal of Finance and Accounting 1: 41-45. [CrossRef]

Amidu, Mohammed, and Simon Wolfe. 2008. The impact of monetary policy on banks' credit in Ghana. Global and Local Dynamics in African Business and Development 9: 1-8.

Anari, Ali, and James Kolari. 2016. Dynamics of interest and inflation rates. Journal of Empirical Finance 39: 129-44. [CrossRef]

Anderson, Thiodor Wilber, and Chang Hsiao. 1981. Estimation of Dynamic Models with Error Components. Journal of the American Statistical Association 76: 598. [CrossRef]

Arbabiyan, Ali Akbar, and Mehdi Safari. 2009. The effects of capital structure and profitability in the listed firms in Tehran Stock Exchange. Journal of Management Perspective 33: 159-75.

Arellano, Manuel, and Stephen Bond. 1991. Some tests of specification for panel data: Monte Carlo evidence and an application to employment equations. The Review of Economic Studies 58: 277-97. [CrossRef]

Athanasoglou, Panayiotis P., Sophocles N. Brissimis, and Manthos D. Delis. 2008. Bank-specific, industry-specific and macroeconomic determinants of bank profitability. Journal of International Financial Markets, Institutions and Money 18: 121-36. [CrossRef]

Badunenko, Oleg, and Subal C. Kumbhakar. 2017. Economies of scale, technical change and persistent and time-varying cost efficiency in Indian banking: Do ownership, regulation and heterogeneity matter? European Journal of Operational Research 260: 789-803. [CrossRef]

Barajas, Adolfo, Roberto Steiner, and Natalia Salazar. 1999. Interest spreads in banking in Colombia, 1974-1996. IMF Staff Papers 46: 196-224.

Barth, James, Daniel Nolle, and Tara Rice. 1997. Commercial Banking Structure, Regulation, and Performance: An International Comparison. Managerial Finance 23: 1-39. [CrossRef]

Bartholdy, Jan, Glenn Boyle, and Roger D. Stover. 1997. Corporate capital structure and regulation of bank equity holdings: Some international evidence. Multinational Finance Journal 1: 63-80. [CrossRef]

Beaver, William H., and Stephen G. Ryan. 2000. Biases and lags in book value and their effects on the ability of the book-to-market ratio to predict book return on equity. Journal of Accounting Research 38: 127-48. [CrossRef]

Beck, Hanno. 2001. Banking is essential; banks are not. The future of financial intermediation in the age of the Internet. Netnomics 3: 7-22. [CrossRef]

Beckmann, Rainer. 2007. The profitability of Western European banking systems: Panel evidence on structural and cyclical determinants. SSRN Electronic Journal, 1090570. [CrossRef] 
Berger, Allen N., Gerald A. Hanweck, and David B. Humphrey. 1987. Competitive viability in banking: Scale, scope, and product mix economies. Journal of Monetary Economics 20: 501-20. [CrossRef]

Bhatti, Ghulam Ali, and Haroon Hussain. 2010. Evidence on structure conduct performance hypothesis in Pakistani commercial banks. International Journal of Business and Management 5: 174. [CrossRef]

Bikker, Jacob A., and Haixia Hu. 2002. Cyclical patterns in profits, provisioning and lending of banks and procyclicality of the new Basel capital requirements. PSL Quarterly Review 55: 143-75.

Birindelli, Giuliana, Paola Ferretti, Mariantonietta Intonti, and Antonia Iannuzzi. 2015. On the drivers of corporate social responsibility in banks: Evidence from an ethical rating model. Journal of Management E Governance 19: 303-40.

Boahene, Samuel Hymore, Julius Dasah, and Samuel Kwaku Agyei. 2012. Credit risk and profitability of selected banks in Ghana. Research Journal of Finance and Accounting 3: 6-14.

Bourke, Philip. 1989. Concentration and other determinants of bank profitability in Europe, North America and Australia. Journal of Banking and Finance 13: 65-79. [CrossRef]

Busu, Mihail. 2019. The Role of Renewables in a Low-Carbon Society: Evidence from a Multivariate Panel Data Analysis at the EU Level. Sustainability 11: 5260. [CrossRef]

Cameron, Adrian Colin, and Pravin K. Trivedi. 2010. Microeconometrics Using Stata. rev. ed. College Station: Stata Press.

Chakraborty, Indrani. 2010. Capital structure in an emerging stock market: The case of India. Research in International Business and Finance 24: 295-314. [CrossRef]

Chandra, Prasanna. 2001. Financial Management, 7th ed. New York: McGraw-Hill.

Chenhall, Robert H., and Frank Moers. 2007. The issue of endogeneity within theory-based, quantitative management accounting research. European Accounting Review 16: 173-96. [CrossRef]

Dan Dang, Van. 2019. Should Vietnamese Banks Need More Equity? Evidence on Risk-Return Trade-Off in Dynamic Models of Banking. Journal of Risk and Financial Management 12: 84. [CrossRef]

Demirguc-Kunt, Asli, and Harry Huizinga. 2001. Financial Structure and Bank Profitability. World Bank Policy Research Working Paper 2430. Washington, DC: World Bank. [CrossRef]

Ebaid, Ibrahim El-Sayed. 2009. The impact of capital-structure choice on firm performance: Empirical evidence from Egypt. The Journal of Risk Finance 10: 477-87. [CrossRef]

Eljelly, Abuzar M. A. 2004. Liquidity-profitability trade-off: An empirical investigation in an emerging market. International Journal of Commerce and Management 14: 48-61. [CrossRef]

Flamini, Valentina, Calvin McDonald, and Liliana Schumacher. 2009. The Determinants of Commercial Bank Profitability in Sub-Saharan Africa (No. 9-15). Washington, DC: International Monetary Fund.

Gakure, R. W., John Karanja Ngugi, Peter Musangi Ndwiga, and Simon Maina Waithaka. 2012. Effect of Credit Risk Management Techniques on The Performance of Unsecured Bank Loans Employed Commercial Banks in Kenya. International Journal of Business and Social Research 2: 221-36.

Gompers, Paul, and Josh Lerner. 1998. Venture capital distributions: Short-run and long-run reactions. The Journal of Finance 53: 2161-83. [CrossRef]

Gounder, Neelesh, and Parmendra Sharma. 2012. Determinants of bank net interest margins in Fiji, a small island developing state. Applied Financial Economics 22: 1647-54. [CrossRef]

Hadri, Kaddour. 2000. Testing for stationarity in heterogeneous panel data. The Econometrics Journal 3: $148-61$. [CrossRef]

Haitovsky, Yoel. 1969. Multicollinearity in regression analysis: Comment. The Review of Economics and Statistics 51: 486-89. [CrossRef]

Hays, Fred H., Stephen A. De Lurgio, and Arthur H. Gilbert Jr. 2009. Efficiency ratios and community bank performance. Journal of Finance and Accountancy 1: 1-15.

Hoggett, Jhon, Jhon Medlin, Keryn Chalmers, Claire Beattie, Andreas Hellmann, and Jodei Maxfield. 2018. Financial Accounting. Milton: John Wiley \& Sons Australia, ISBN 9780730344575.

Huang, Bwo-Nung, M. J. Hwang, and Chin W. Yang. 2008. The causal relationship between energy consumption and GDP growth revisited: A dynamic panel data approach. Ecological Economics 67: 41-54. [CrossRef]

Jizi, Mohammad I., and Robert Dixon. 2017. Are risk management disclosures informative or tautological? Evidence from the US banking sector. Accounting Perspectives 16: 7-30. [CrossRef] 
Khan, Mahmood Ul Hassan, and Muhammad Nadeem Hanif. 2019. Empirical evaluation of 'structure-conduct performance' and 'efficient-structure' paradigms in the banking sector of Pakistan. International Review of Applied Economics 33: 682-96. [CrossRef]

Khan, Abdul Aleem, Qazi Masood Ahmed, and Kalim Hyder. 2007. Determinants of Recent Inflation in Pakistan. MPRA Paper No. 16254. Available online: https://mpra.ub.uni-muenchen.de/16254/ (accessed on 8 February 2020).

Kolapo, T. Funso, R. Kolade Ayeni, and M. Oja Oke. 2012. Credit risk and commercial banks' performance in Nigeria: A panel model approach. Australian Journal of Business and Management Research 2: 31.

Kosmidou, Kyriaki. 2008. The determinants of banks' profits in Greece during the period of EU financial integration. Managerial Finance 34: 146-59. [CrossRef]

Levin, Andrew, Chien-Fu Lin, and Chia-Shang James Chu. 2002. Unit root tests in panel data: Asymptotic and finite-sample properties. Journal of Econometrics 108: 1-24. [CrossRef]

Levine, Ross. 1996. Foreign banks, financial development, and economic growth. International Financial Markets: Harmonisation Versus Competition 7: 224-54.

Mamatzakis, Emmanuel, and Panagiotis Remoundos. 2003. Determinants of Greek commercial banks, 1989-2000. Spoudai 53: 84-94.

Manawaduge, Athula, Anura De Zoysa, Khorshed Chowdhury, and Anil Chandarakumara. 2011. Capital structure and firm performance in emerging economies: An empirical analysis of Sri Lankan firms. Corporate Ownership \& Control 8: 253-63.

Mansfield, Edward R., and Billy P. Helms. 1982. Detecting multicollinearity. The American Statistician 36: 158-60.

Marimuthu, Maran. 2008. Ethnic Diversity on Boards of Directors and Its Implications on Firm Financial Performance. The Journal of International Social Research 1: 431-45.

Matherat, Sylvie. 2008. Fair value accounting and financial stability: Challenges and dynamics. Financial Stability Review 12: 53-64.

Memon, Fozia, Niaz Ahmedd Bhutto, and Ghulam Abbas. 2012. Capital structure and firm performance: A case of textile sector of Pakistan. Asian Journal of Business and Management Sciences 1: 9-15.

Miller, Stephen M., and Athanasios G. Noulas. 1997. Portfolio mix and large-bank profitability in the USA. Applied Economics 29: 505-12. [CrossRef]

Modigliani, Franco, and Merton H. Miller. 1958. The cost of capital, corporation finance and the theory of investment. The American Economic Review 48: 261-97.

Molyneux, Philip, and John Thornton. 1992. Determinants of European bank profitability: A note. Journal of Banking E Finance 16: 1173-78.

Mordi, Charles N. O. 2010. The link between the financial (banking) sector and the real sector of the Nigerian economy. Economic and Financial Review 48: 7-30.

Mule, Robert Kisavi, Mohamed Suleiman Mukras, and Onesmus Mutunga Nzioka. 2015. Corporate size, profitability and market value: An econometric panel analysis of listed firms in Kenya. European Scientific Journal, ESJ 11: 376-96.

Muritala, Taiwo Adewale. 2012. An empirical analysis of capital structure on firms' performance in Nigeria. International Journal of Advances in Management and Economics 1: 116-24.

Naceur, Sami Ben, and Mohamed Goaied. 2008. The determinants of commercial bank interest margin and profitability: Evidence from Tunisia. Frontiers in Finance and Economics 5: 106-30. [CrossRef]

Naceur, Sami Ben, and Mohammed Omran. 2011. The effects of bank regulations, competition, and financial reforms on banks' performance. Emerging Markets Review 12: 1-20. [CrossRef]

Nelson, Charles R., and Charles R. Plosser. 1982. Trends and random walks in macroeconomic time series: Some evidence and implications. Journal of Monetary Economics 10: 139-62. [CrossRef]

Nickell, Stephen. 1981. Biases in Dynamic Models with Fixed Effects. Econometrica 49: 1417. [CrossRef]

Nikoo, Seyedeh Farokh. 2015. Impact of capital structure on banking performance: Evidence from Tehran Stock Exchange. International Research Journal of Applied and Basic Sciences 9: 923-27.

Niresh, Aloy, and T. Velnampy. 2014. Firm size and profitability: A study of listed manufacturing firms in Sri Lanka. International Journal of Business and Management 9: 57-64. [CrossRef]

Njanike, Kosmas. 2009. The impact of effective credit risk management on bank survival. Annals of the University of Petrosani, Economics 9: 173-84. 
Ogboi, Charles, and Okaro Kenneth Unuafe. 2013. Impact of credit risk management and capital adequacy on the financial performance of commercial banks in Nigeria. Journal of Emerging Issues in Economics, Finance and Banking 2: 703-17.

Papadopoulos, Simeon. 2010. New evidence on banking efficiency in Europe. International Journal of Monetary Economics and Finance 3: 280-99. [CrossRef]

Ramadan, Zeyad, and Imad Ramadan. 2015. Capital structure and firm's performance of Jordanian manufacturing sector. International Journal of Economics and Finance 7: 279-84. [CrossRef]

Ransbotham, Sam, and David Kiron. 2017. Analytics as a source of business innovation. MIT Sloan Management Review 58: 1-16.

Revell, Jack. 1979. Inflation and Financial Institutions. London: The Financial Times.

Rosli, Mohamad Hafiz, Nurru Ain Fauzi, Muhammad Fadhirul Anuar Mohd Azami, Farahwahida Binti Mohd, and Jamaliah Said. 2016. Company characteristics and corporate social responsibility disclosure of Malaysian listed companies. Paper presented at the International Conference on Accounting Studies (ICAS) 2016, Langkawi, Kedah, Malaysia, August 15-18.

Salim, Mahfuza, and Raj Yadav. 2012. Capital structure and firm performance: Evidence from Malaysian listed companies. Procedia-Social and Behavioral Sciences 65: 156-66. [CrossRef]

Salteh, Heydar Mohammadzadeh, Elham Ghanavati, Vahid Taghizadeh Khanqah, and Mohsen Akbari Khosroshahi. 2012. Capital structure and firm performance; Evidence from Tehran Stock Exchange. International Proceedings of Economics Development E Research 43: 225-30.

Santos, Joao A. C., and Javier Suarez. 2019. Liquidity standards and the value of an informed lender of last resort. Journal of Financial Economics 132: 351-68. [CrossRef]

Scholtens, Bert, and Dick Van Wensveen. 2000. A critique on the theory of financial intermediation. Journal of Banking and Finance 24: 1243-51. [CrossRef]

Seven, Unal, and Hakan Yetkiner. 2016. Financial intermediation and economic growth: Does income matter? Economic Systems 40: 39-58. [CrossRef]

Shah, Attaullah, Jamil Ur Rehman, Yasir Kamal, and Zaheer Abbas. 2010. The interest rates-stock prices nexus in highly volatile markets: Evidence from Pakistan. Journal of Basic and Applied Scientific Research 2: 2589-98.

Shepherd, William G. 1972. The elements of market structure. The Review of Economics and Statistics 54: 25-37. [CrossRef]

Short, Brock K. 1979. The relation between commercial bank profit rates and banking concentration in Canada, Western Europe, and Japan. Journal of Banking and Finance 3: 209-19. [CrossRef]

Smirlock, Michael. 1985. Evidence on the (non) relationship between concentration and profitability in banking. Journal of Money, Credit and Banking 17: 69-83. [CrossRef]

Song, Xiaoling, Xin Deng, and Ruixue Wu. 2019. Comparing the Influence of Green Credit on Commercial Bank Profitability in China and Abroad: Empirical Test Based on a Dynamic Panel System Using GMM. International Journal of Financial Studies 7: 64. [CrossRef]

Soumadi, Mustafa M., and Osama Suhail Hayajneh. 2012. Capital structure and corporate performance empirical study on the public Jordanian shareholdings firms listed in the Amman stock market. European Scientific Journal 8: 173-89.

Sritharan, Vinasithamby. 2015. Does firm size influence on firm's profitability? Evidence from listed firms of Sri Lankan hotels and travels sector. Research Journal of Finance and Accounting 6: 201-7.

Staikouras, Christos K., and Geoffrey E. Wood. 2004. The determinants of European bank profitability. International Business and Economics Research Journal 3: 57-68. [CrossRef]

Subayyal, Muhammad, and Attaullah Shah. 2011. The cointegration between exchange rates and stock prices in highly volatile markets: Evidence from Pakistan. Middle Eastern Finance and Economics 15: 156-63.

Tan, Yong. 2016. The impacts of risk and competition on bank profitability in China. Journal of International Financial Markets, Institutions and Money 40: 85-110. [CrossRef]

Tan, Yong. 2017. The impacts of competition and shadow banking on profitability: Evidence from the Chinese banking industry. The North American Journal of Economics and Finance 42: 89-106. [CrossRef]

Tan, Yong, and Christos Floros. 2012a. Bank profitability and inflation: The case of China. Journal of Economic Studies 39: 675-96. [CrossRef]

Tan, Yong, and Christos Floros. 2012b. Bank profitability and GDP growth in China: A note. Journal of Chinese Economic and Business Studies 10: 267-73. [CrossRef] 
Tan, Yong, and Christos Floros. 2012c. Stock market volatility and bank performance in China. Studies in Economics and Finance 29: 211-28. [CrossRef]

Tan, Yong, Christos Floros, and John Anchor. 2017. The profitability of Chinese banks: Impacts of risk, competition and efficiency. Review of Accounting and Finance 16: 86-105. [CrossRef]

Thakor, Anjan V. 2018. Post-crisis regulatory reform in banking: Address insolvency risk, not illiquidity! Journal of Financial Stability 37: 107-11. [CrossRef]

Tongkong, Supa. 2012. Key factors influencing capital structure decision and its speed of adjustment of Thai listed real estate companies. Procedia-Social and Behavioral Sciences 40: 716-20. [CrossRef]

Umar, Muhammad, Zaighum Tanveer, Saeed Aslam, and Muhammad Sajid. 2012. Impact of capital structure on firms' financial performance: Evidence from Pakistan. Research Journal of Finance and Accounting 3: 1-12.

Vallelado, Teyo, and Paolo Saona. 2011. An integrated model of capital structure to study the differences in the speed of adjustment to target corporate debt maturity among developed countries. International Journal of Banking, Accounting and Finance 3: 258-93. [CrossRef]

Van Lent, Laurence. 2007. Endogeneity in management accounting research: A comment. European Accounting Review 16: 197-205. [CrossRef]

Willis, Cleve E., and Robert D. Perlack. 1978. Multicollinearity: Effects, symptoms, and remedies. Journal of the Northeastern Agricultural Economics Council 7: 55-61. [CrossRef]

Yoo, Wonsuk, Robert Mayberry, Sejong Bae, Karan Singh, Qinghua Peter He, and James W. Lillard Jr. 2014. A study of the effects of multicollinearity in the multivariable analysis. International Journal of Applied Science and Technology 4: 9. [PubMed]

Zheng, Changun, Shumaila Meer Perhiar, Naeem Gul Gilal, and Faheem Gul Gilal. 2019. Loan Loss Provision and Risk-Taking Behavior of Commercial Banks in Pakistan: A Dynamic GMM Approach. Sustainability 11: 5209. [CrossRef]

(C) 2020 by the authors. Licensee MDPI, Basel, Switzerland. This article is an open access article distributed under the terms and conditions of the Creative Commons Attribution (CC BY) license (http://creativecommons.org/licenses/by/4.0/). 